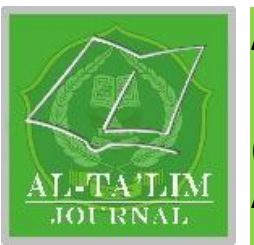

AL-TA'LIM JOURNAL, 24 (1), 2017, (47-52)

(Print ISSN 1410-7546 Online ISSN 2355-7893)

Available online at http://journal.tarbiyahiainib.ac.id/index.php/attalim

\title{
Agriculture Students' Ability to Write Past Tense at Taman Siswa University of Padang
}

Received: 24 $4^{\text {th }}$ January 2017; Revised:19 ${ }^{\text {th }}$ Febuary 2017; Accepted: $31^{\text {th }}$ March 2017

Permalink/DOI: http://dx.doi.org/10.15548/jt.v24i1.259

\author{
Amal Hayati \\ Sekolah Tinggi Keguruan dan Ilmu \\ Pendidikan Dharma Bakti Lubuk Alung \\ Sumatera Barat, Indonesia \\ E-mail : mel_maganda@yahoo.com
}

\begin{abstract}
The purpose of this research is to describe the third semester agriculture students' ability to write simple sentences using simple past tense at Taman Siswa University Padang. This research was limited in three sentence forms; affirmative, negative and interrogative. Descriptive research was used in this study where the population was the third semester agriculture students at Taman Siswa University of Padang. The total number of the sample was 63 students. The finding showed that the ability of the third semester agriculture students of Taman Siswa University of Padang to write simple sentences using simple past tense was moderate. It could be seen that $70.97 \%$ students have moderate ability. In detail the percentages of each of form sentence were; $64.52 \%$ have moderate ability to write simple sentences in simple past tense of (verbal) affirmative, $74.20 \%$ have moderate ability to write simple sentences in simple past tense of (verbal) negative sentences, and $77.42 \%$ have moderate ability to write simple sentences in simple past tense of (verbal) interrogative sentences. Based on the research finding, it is suggested to the teachers to give more explanation about past tense and explain the usage of mechanics. The students are suggested to learn more about past tense and use mechanics correctly.
\end{abstract}

Keywords: Writing ability, simple sentences, past tense

How to Cite: Hayati, A. (2017). Agriculture students' ability to write past tense at Taman Siswa university of Padang. Al-Ta Lim Journal, 24(1). doi:http://dx.doi.org/10.15548/jt.v24i1.259

\section{INTRODUCTION}

Nowadays, foreign language students should prepare themselves to face the condition of globalization era. It means that they should be able to master English well (Rahmalia, 2016; Sari \& Nufus, 2016). It is not only expected to be able to communicate in spoken but also to communicate in written form. In this era, the students should be able to compete in getting information from many sources that are provided in English.
There are four skills that should be mastered for English students; speaking, listening, reading, and writing. Language components like vocabulary, grammar, and pronunciation are also needed in mastering English.

For Indonesian students, English becomes a compulsory subject to study at university level. By studying grammar seriously, the learner can arrange the words into sentences, from the word that does not 
have meaning into sentences that have meaning.

According to Seaton \& Mew (2007), sentence is a group of words that expresses a complete thought. A sentence must have a subject and a verb, but it may or may not have an object. In addition, Biber (2010) states that sentence is a group of words that contains a subject and a verb, and can stand on its own as a complete thought.

There are many kinds of sentences. (Oshima \& Hogue, 2006) explains that sentence is a group of words that contains at least one subject, one object and one verb and expresses a complete thought. The sentence can be categorized into: (1) simple sentence, (2) compound sentence, (3) complex sentence and (4) compound-complex sentence.

In writing a sentence, students should know the grammar. Grammar is one of the components in language learning that has been taught how to use words. According to (Cook, 2013) states that grammar is the way how a language constructed when we speak, listen, write and read. It is evidence that grammar cannot be ignored.

In addition, Kieffer \& Lesaux (2007) defines that grammar as the rules that construct the group of the words in a language into a meaningful. There are many tenses in English language. They are simple present tense, present progressive (present continuous tense), present perfect tense, present perfect continuous tense, simple past tense, past continuous tense, past perfect tense, past perfect continuous tense, future tense, future continuous tense, future perfect tense, future perfect continuous tense, past future tense, past future continuous tense, past future perfect tense, and past future perfect continuous tense. Among those tenses, simple past tense is most used in daily communication.

Besides, (Disterheft, 2004) says grammar as system of rules that every speaker formulates through the process of first language acquisition. It means, studying grammar is very important in English and it can help one to learn about a language. By studying grammar seriously, the learner is able to make the words into sentences, from the word that does not have meaning into sentences that has meaning

Quirk (2010) and Rutherford (2014) state that grammar is a set of shared assumption about how language. Grammar can also mean a description of the language system. As system of rules, every speaker formulates through the process of first language acquisition. It means, studying grammar is very important in English and it can help one to learn about a language.

Tenses are one element in the English language that is difficult to understand by Indonesian people who learn English because there are no tenses in Indonesian. Gunn \& McCallum (2005) says that the tense of verb shows the action of the verb happens in the past, the present or the future, whether it is a single action or repeated action, whether the action completed or incomplete. In addition, Disterheft (2004) says tense refers to the actual form that a verb takes, for example, whether it is a present or a past form. It can be concluded that among many tenses, past tense is mostly used in both written and oral communication in the classroom. Thus, it is one of main reasons that this tense is analyzed in this research.

Based on the researcher's experience teaching English at the third semester of agriculture students at Taman Siswa University of Padang, most of the students had difficulties in writing sentence in past tense. In fact, the students' ability to write sentence was still not satisfactory. It was identified from the result of their exercises in writing simple sentences in simple past tense. They got problem to write sentences because they forgot the pattern and they did not know the verb. Besides they were confused in using some indicators such as form of verb, time signal and usage of did.

Based on the description above, the researcher is interested in conducting a 
research to analyzed Agriculture students' ability to write past tense at Taman Siswa University of Padang.

\section{METHOD}

The design of this research was a descriptive in research. Descriptive research involves collecting data in order to answer question concerning the current status of the subject of the study (Ary, Jacobs, Sorensen, \& Walker, 2013). It is also supported by (Gay, Mills, \& Airasian, 2011) descriptive research is useful in investigating many kinds of educational problem.

\section{Population and Sample}

The population of this research was the third semester agriculture students of Taman Siswa University Padang. Total number of population was 63 students which divided into two classes.

The researcher used cluster random sampling technique to select the sample. According to (Gay et al., 2011), cluster random sampling is sampling techniques in which the sample is in group and not individual are randomly selected, and all members of selected group have similar characteristics. The selected sample was 31 students.

\section{Instrument of the Research}

The instrument for collecting the data in this research was writing test in the form of writing sentences. In this research, the researcher asked the students to write ten simple sentences in simple past tense of (verbal) affirmative sentences, ten simple sentences in simple past tense of (verbal) negative sentences, and also ten simple sentences in simple past tense of (verbal) interrogative sentences. The students were given 60 minutes to do the test.

To know the validity of the test, the researcher used content validity in which the test materials were constructed based on the syllabus and teaching materials. As (Gay et al., 2011) says that content validity is the degree to which a test measures an intended content area. To analyze the data, the researcher would follow the procedures as follow:

a. Calculating mean (M) and Standard Deviation (SD). To calculate mean, the researcher uses the following formula (Arikunto, 2010)

Where:

$$
M=\frac{\sum x}{N}
$$

$$
\begin{aligned}
M & =\text { Mean } \\
N & =\text { Number of the students } \\
\sum_{x} & =\text { the total score of the students }
\end{aligned}
$$

b. To calculate Standard Deviation (SD), the researcher used the following formula (Arikunto, 2010)

$$
S D=\sqrt{\frac{\sum x^{2}}{N}-\left(\frac{\sum x}{N}\right)^{2}}
$$

Where:

SD $=$ Standard Deviation

$\sum_{x}=$ the total score of the students

$\sum_{x} 2=$ the sum of all the squares; square of each score and add up the squares

$\mathrm{N}=$ Number of the students

c. Classifying the students' ability into high, moderate or low ability by using the following categories (Arikunto, 2010):

$$
\begin{aligned}
& >\mathrm{M}+\mathrm{SD}=\text { High } \\
& \mathrm{M}-\mathrm{SD} \rightarrow \mathrm{M}+\mathrm{SD}=\text { Moderate } \\
& <\mathrm{M}-\mathrm{SD}=\text { Low }
\end{aligned}
$$

d. Calculating the percentage of the students who get high, moderate or low ability by using the following formula:

$$
P=\frac{R}{T} x 100 \%
$$

Where:

$\mathrm{P}=$ Percentage of the students who get each ability.

$\mathrm{R}=$ the sum of the students who get high, moderate or low ability.

$\mathrm{T}=$ the sum of the students. 
RESULTS AND DISCUSSIONS

\section{Students' Ability to Write Simple Sentences Using Simple Past Tense}

As Sapir (2014) says that a sentence is a group of words that contains a subject and a verb, and can stand on its own as a complete thought. Example: "The world is a stage." The subject is "the world" while the verb is "is"; the complete thought involves comparing the world to a stage.

The data gotten from students writing test, the maximum possible score of writing simple sentences in the simple past tense was 150 if students' sentences consist of all criteria. The researcher found the highest score of the students to write simple sentence using simple past tense was at 148 and the lowest score was 73.5.

Then, the researcher calculated the Mean and Standard Deviation. The result of Mean was 122.06 and Standard Deviation was 17.08. The result showed that 5 students $(16.13 \%)$ had high ability, 22 students (70.97\%) had moderate ability and 4 students (12.90) had low.

Table 1. The Percentage of Students' Ability to Write Simple Sentences Using Simple Past Tense

\begin{tabular}{lcc}
\hline Quality & $\begin{array}{c}\text { Number of } \\
\text { Students }\end{array}$ & The Percentage \\
\hline High & 5 & $16.13 \%$ \\
Moderate & 22 & $70.97 \%$ \\
Low & 4 & $12.90 \%$ \\
Total & 31 & $100 \%$ \\
\hline
\end{tabular}

The table above describes the ability of the third semester agriculture students of Taman Siswa Padang to write simple sentences using simple past tense was moderate.

Mittwoch (2008) state that the simple past tense describes actions or activities that began and ended in the past. There are some time expressions in using past tense such as ago, first, then, later, finally, last (and other sequence expression). Past tense expresses activity or state in the past without indicating any connection with the present or future.

\section{Students' Ability to Write Simple Sentences in Simple Past Tense of (Verbal) Affirmative Sentences}

This part presents the students' ability to write simple sentences in simple past tense of (verbal) affirmative sentences. The maximum possible score for this component was 40. The results showed that the highest score was 40 and the lowest score was 21.5. After that, the researcher counted Mean and Standard Deviation.

The result of students' ability to write simple sentences in simple past tense of (verbal) affirmative sentences can be describe in the following table:

Table 2. The Percentage of Students' Ability to Write Simple Sentences in Simple Past Tense of (Verbal) Affirmative Sentences

\begin{tabular}{|c|c|c|}
\hline Quality & $\begin{array}{l}\text { Number of } \\
\text { Students }\end{array}$ & The Percentage \\
\hline High & 7 & $22.58 \%$ \\
\hline Moderate & 20 & $64.52 \%$ \\
\hline Low & 4 & $12.90 \%$ \\
\hline Total & 31 & $100 \%$ \\
\hline
\end{tabular}

The table above describes the result of Mean was 32.27 and Standard Deviation was 4.49. The result showed that 7 students $(22.58 \%)$ had high ability, 20 students $(64.52 \%)$ had moderate ability and 4 students $(12.90 \%)$ had low ability. It means that the ability of the third semester agriculture students of Taman Siswa Padang to write simple sentences in simple past tense of (verbal) affirmative sentences was moderate.

According to (Biber, 2010), the simple past tense is the time used explains an action or events at the specific time in the past in the form of modestly. It is used for, first, the simple past tense expresses an action which has done art has finished in the past or describes an event that happened in the specific time in the past for example "he helped me last week". Second, the simple past 
tense expresses the habitual action in the past but it does not happen in this time for example "he worked in the restaurant" but now he is working in a factory. Third, the simple past tense expresses a situation that happened in the past for example "we were at home last night".

\section{Students' Ability to Write Simple Sentences in Simple Past Tense of (Verbal) Negative Sentences}

The maximum possible score for this component was 60 . The result showed that the highest score was 60 and the lowest score was 29. The researcher calculated Mean and Standard Deviation. The result of Mean was 50.27 and Standard Deviation was 7.65. It can be seen on the following table.

Table 3. The Percentage of Students' Ability to Write Simple Sentences in Simple Past Tense of (Verbal) Negative Sentences

\begin{tabular}{lll}
\hline \multicolumn{1}{c}{ Quality } & \multicolumn{1}{c}{$\begin{array}{c}\text { Number of } \\
\text { Students }\end{array}$} & The Percentage \\
\hline High & 4 & $12.90 \%$ \\
Moderate & 23 & $74.20 \%$ \\
Low & 4 & $12.90 \%$ \\
Total & 31 & $100 \%$ \\
\hline
\end{tabular}

The result of calculation showed that 4 students $(12.90 \%)$ had high ability, 23 students $(74.20 \%)$ had moderate ability, 4 students (12.90) had low ability. It means that in general the ability of the third semester agriculture students of Taman Siswa Padang to write simple sentences in simple past tense of (verbal) negative sentences was moderate.

According to (Puspika \& Narius, 2014), the simple past tense refers to the activity ended in the past, the expression of the time can be neglected from the pattern. The expression of past time specify the time in the past when an action was completed.

\section{Students' Ability to Write Simple Sentences in Simple Past Tense of (Verbal) Interrogative Sentences}

The maximum score for this component was 50. The result showed that the highest score was 49 and the lowest score was 19. After that, the researcher counted the Mean and Standard Deviation. The result of Mean was 39.52 and Standard Deviation 7.12. It can be seen on the following table.

Table 4. The Percentage of Students' Ability to Write Simple Sentences in Simple Past Tense of (Verbal) Interrogative Sentences

\begin{tabular}{lcl}
\hline Quality & $\begin{array}{c}\text { Number of } \\
\text { Students }\end{array}$ & $\begin{array}{c}\text { The } \\
\text { Percentage }\end{array}$ \\
\hline High & 3 & $9.68 \%$ \\
Moderate & 24 & $77.42 \%$ \\
Low & 4 & $12.90 \%$ \\
Total & 31 & $100 \%$ \\
\hline
\end{tabular}

The result of this calculation showed that there were 3 students $(9.68 \%)$ had high ability, 24 students $(77.42 \%) \%$ ) had moderate ability, and 4 students $(12.90 \%)$ had low ability. From the calculation of this result, it could be seen that the ability of the third semester agriculture students of Taman Siswa of Padang to write simple sentences in simple past tense of (verbal) interrogative sentences was moderate. Furthermore, (Uchiyama, 2006), explains the past tense can be used for most past actions, there are some usages of past tense, such as; actions that happened quickly. Actions that happened over time, and actions that were habits in the past.

\section{CONCLUSION AND RECOMMENDATION}

In general, it can be concluded that the ability of the third semester agriculture students of Taman Siswa Padang to write simple sentences using simple past tense was moderate. This conclusion was indicated by the fact they were 5 students $(16.13 \%)$ who had high ability, 22 students $(70.97 \%)$ who had moderate, and 4 students (12.90) who had low ability to write simple sentences using simple past tense.

Based on the conclusions above, the researcher gives some recommendation to teachers, students, and further researcher. For English teachers, since the students' ability to write simple sentences using simple past tense 
was moderate, the teachers should give more explanations about simple past tense and the teacher also asks students to remind regular and irregular verb that will be used to write verbal affirmative sentences in simple past tense. Besides that, teachers also explain how to use mechanics (capitalization, punctuation and spelling) in writing sentences. For the students, they are suggested to learn more about past tense especially irregular verb and how to use mechanics in writing sentences and they are also suggested to pay attention to use "did" and "not". Last, for the further researcher, the researcher suggests to find out the difficulties of the students to write simple sentences using simple past tense.

\section{REFERENCES}

Arikunto, S. (2010). Edisi Revisi: Manajeman Penelitian. Jakarta: PT. Rineka Cipta.

Ary, D., Jacobs, L. C., Sorensen, C. K., \& Walker, D. (2013). Introduction to research in education. Cengage Learning.

Biber, D. (2010). Longman Student Grammer of Spoken and Written English. Pearson Education India.

Cook, V. (2013). Second language learning and language teaching. Routledge.

Disterheft, D. (2004). Advanced Grammar: A Manual for Students. Pearson/Prentice Hall.

Gay, L. R., Mills, G. E., \& Airasian, P. W. (2011). Educational research: Competencies for analysis and applications. Pearson Higher Ed.

Gunn, C., \& McCallum, A. (2005). Climbing grammar mountain: An interactive learning experience. In English Teaching Forum (Vol. 43, pp. 38-45).
Kieffer, M. J., \& Lesaux, N. K. (2007). Breaking down words to build meaning: Morphology, vocabulary, and reading comprehension in the urban classroom. The Reading Teacher, 61(2), 134-144.

Mittwoch, A. (2008). The English resultative perfect and its relationship to the experiential perfect and the simple past tense. Linguistics and Philosophy, 31(3), 323-351.

Oshima, A., \& Hogue, A. (2006). Writing Academic Writing. New York: Addison Wesley Longman.

Puspika, D., \& Narius, D. (2014). Applying quantum technique in teaching grammar to senior high school students. Journal of English Language Teaching, 2(2), 48-54.

Quirk, R. (2010). A comprehensive grammar of the English language. Pearson Education India.

Rahmalia, I. (2016). Students' Linguistic Competence in Essay Writing. Al-Ta Lim Journal, 23(3), 241-248.

Rutherford, W. E. (2014). Second language grammar: Learning and teaching. Routledge.

Sapir, E. (2014). Language. Cambridge University Press.

Sari, N., \& Nufus, H. (2016). The Effect of Using Cooking Academy Game towards Students' Writing Ability. AlTa Lim Journal, 23(3), 191-200.

Seaton, A., \& Mew, Y. H. (2007). Basic English Grammar: For English language learners B. 2. Saddleback Educational Publishing.

Uchiyama, K. (2006). English Verb Tenses. New York. 